In cooperation with the Louisiana Department of Transportation and Development

\title{
Water Resources of Ouachita Parish
}

\section{Introduction}

Ouachita Parish, located in north-central Louisiana (fig. 1), contains fresh groundwater and surface-water resources. In 2005, about 152 million gallons per day (Mgal/d) were withdrawn from water sources in Ouachita Parish (fig. 2). About 84 percent $(128 \mathrm{Mgal} / \mathrm{d})$ was withdrawn from surface water, and 16 percent $(24 \mathrm{Mgal} / \mathrm{d})$ was withdrawn from groundwater (table 1). Power generation (87 Mgal/d) accounted for 58 percent of the total water withdrawn (table 2). Withdrawals for other uses included public supply (22 Mgal/d), industrial (24 $\mathrm{Mgal} / \mathrm{d})$, and irrigation (18 Mgal/d).

This fact sheet summarizes basic information on the water resources of Ouachita Parish, La. Information on groundwater and surface-water availability, quality, development, use, and trends is based on previously published reports.
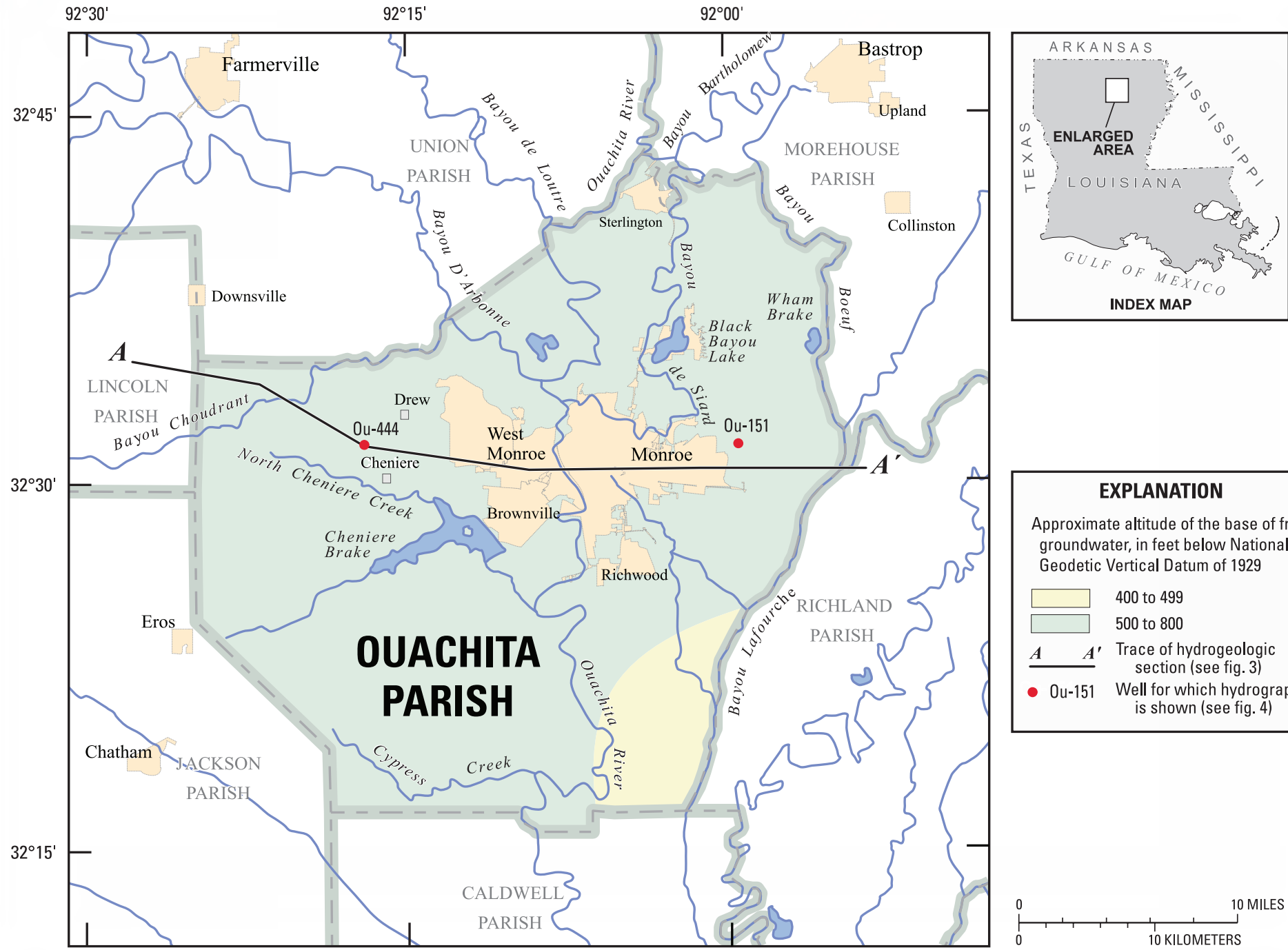

Base modified from Official Map of Louisiana, Louisiana Department of Transportation and Development, 1986

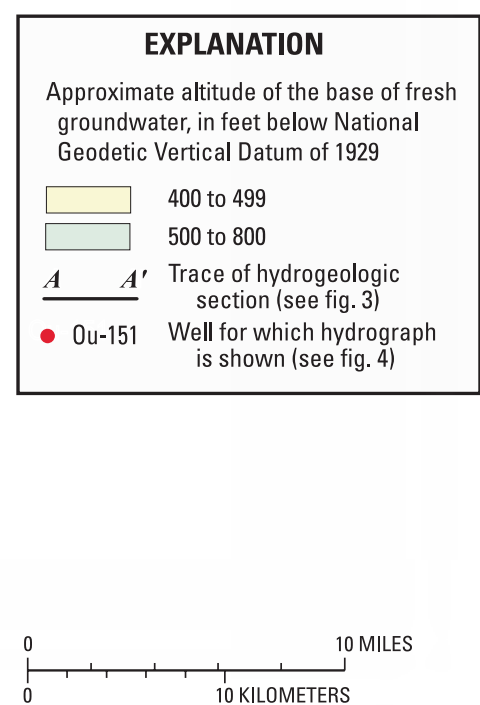

Figure 1. Location of study area, Ouachita Parish, Louisiana. 


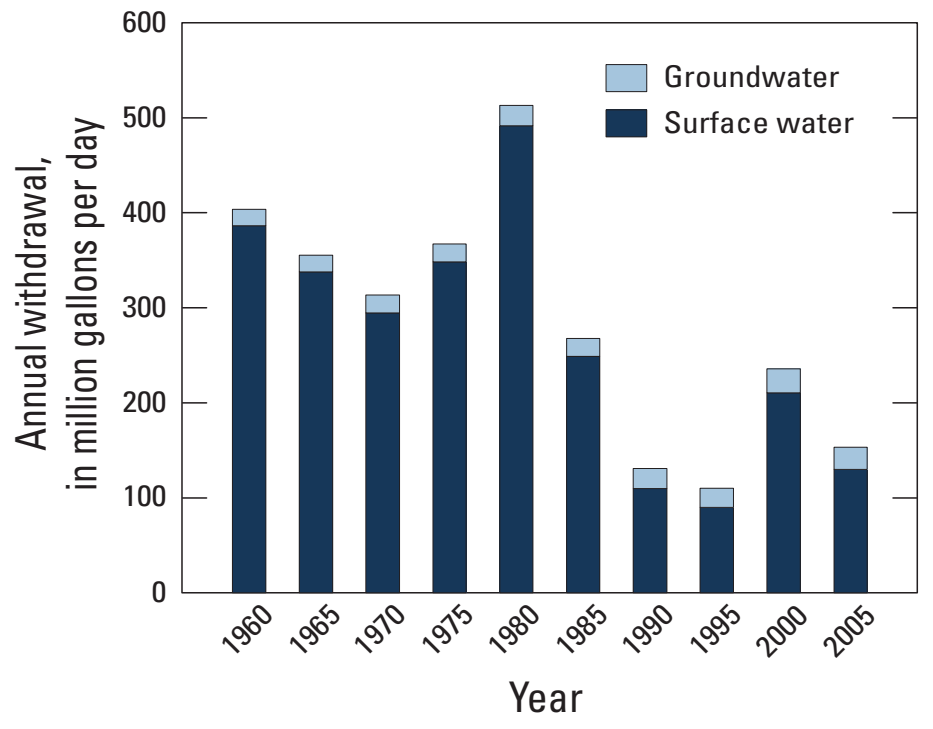

Figure 2. Water withdrawals in Ouachita Parish, Louisiana, 1960-2005.

Table 1. Water withdrawals, in million gallons per day, by source in Ouachita Parish, Louisiana, 2005 (Sargent, 2007).

\begin{tabular}{lcc}
\hline $\begin{array}{c}\text { Aquifer or major } \\
\text { surface-water body }\end{array}$ & Groundwater & Surface water \\
\hline Shallow aquifers & 1.20 & \\
Sparta aquifer & 22.32 & \\
Ouachita River & & 105.37 \\
Bayou de Siard & 11.05 \\
Bayou Lafourche & & 5.22 \\
Other water bodies & & 6.39 \\
Total & 23.52 & 128.02 \\
\hline
\end{tabular}

Table 2. Water withdrawals, in million gallons per day, by category of use in Ouachita Parish, Louisiana, 2005

(Sargent, 2007).

\begin{tabular}{lccr}
\hline Category of use & Groundwater & Surface water & \multicolumn{1}{c}{ Total } \\
\hline Public supply & 10.83 & 11.07 & 21.90 \\
Industrial & 11.00 & 12.91 & 23.91 \\
Power generation & & 87.23 & 87.26 \\
Rural domestic & .43 & & .43 \\
Livestock & & .05 & .05 \\
Rice irrigation & .84 & 13.00 & 13.84 \\
General irrigation & .43 & 3.70 & 4.13 \\
Aquaculture & & .02 & .02 \\
\cline { 2 - 4 } Total & 23.52 & 128.02 & 151.54 \\
\hline
\end{tabular}

\section{Groundwater Resources}

The groundwater resources of Ouachita Parish, from near surface to deepest, include the upland terrace, Mississippi River alluvial, Ouachita River alluvial, Cockfield, and Sparta aquifers (fig. 3). Fresh groundwater is present from land surface to about 800 feet (ft) below National Geodetic Vertical Datum of 1929 (NGVD 29) (sea level) in the parish. Recharge to the aquifers is typically from infiltration of rainfall in outcrop areas, seasonal inflow from rivers, and leakage from overlying aquifers. Discharge from the aquifers is by seasonal outflow to rivers, leakage into underlying aquifers, and withdrawal from wells. Well-registration records from the Louisiana Department of Transportation and Development (DOTD) indicate in Ouachita Parish there are nearly 700 active wells screened in the aquifers: about 365 domestic, 115 irrigation, 55 industrial, and 160 public-supply wells.

\section{Shallow Aquifers}

For the purpose of this fact sheet, the upland terrace, Mississippi River alluvial, Ouachita River alluvial, and Cockfield aquifers are grouped as shallow aquifers. These aquifers generally are near land surface at depths shallower than 100 to $250 \mathrm{ft}$ below NGVD 29.

The upland terrace aquifer is present as a narrow, northto-south band west of the Ouachita River in central Ouachita Parish. The aquifer is present east of Bayou de Siard in the northeastern corner of the parish. In central Ouachita Parish, the aquifer is generally thin, rarely more than $100 \mathrm{ft}$ in thickness, and consists of basal gravel that grades upward into sand, silt, and clay. In some areas of central Ouachita Parish, much of the aquifer may be unsaturated and only suitable for low-yielding wells. In northeastern Ouachita Parish, the upland terrace aquifer has better potential for supplying wells. Previous investigators reported that yields of 500 to $1,000 \mathrm{gal} / \mathrm{min}$ (gallons per minute) may be possible where the aquifer thickens to more than $100 \mathrm{ft}$. The upland terrace aquifer is continuous with alluvial aquifers in northeastern Ouachita Parish. Water in the upland terrace aquifer ranges from soft (0 $60 \mathrm{mg} / \mathrm{L}$ [milligrams per liter] as calcium carbonate) to hard (121-180 $\mathrm{mg} / \mathrm{L}$ as calcium carbonate), and contains concentrations of iron that exceed the U.S. Environmental Protection Agency's (EPA) Secondary Maximum Contaminant Level (SMCL) ${ }^{1}$ for drinking water of $300 \mu \mathrm{g} / \mathrm{L}$ (micrograms per liter).

The Mississippi River and Ouachita River alluvial aquifers are present at or near land surface in the eastern half of Ouachita Parish. The aquifers contain basal gravel overlain with sand, silt, and clay. The aquifers generally contain $20-50 \mathrm{ft}$ of sand and gravel and reported well yields of as much as $330 \mathrm{gal} / \mathrm{min}$. Water from the alluvial aquifers is hard and generally exceeds the EPA's SMCLs for color, iron, and manganese (table 3).

${ }^{1}$ The SMCLs are nonenforceable Federal guidelines regarding cosmetic effects (such as tooth or skin discoloration) or aesthetic effects (such as taste, odor, or color) of drinking water. At high concentrations or values, health implications as well as aesthetic degradation might exist. SMCLs were established as guidelines for the States by the U.S. Environmental Protection Agency (1992). 


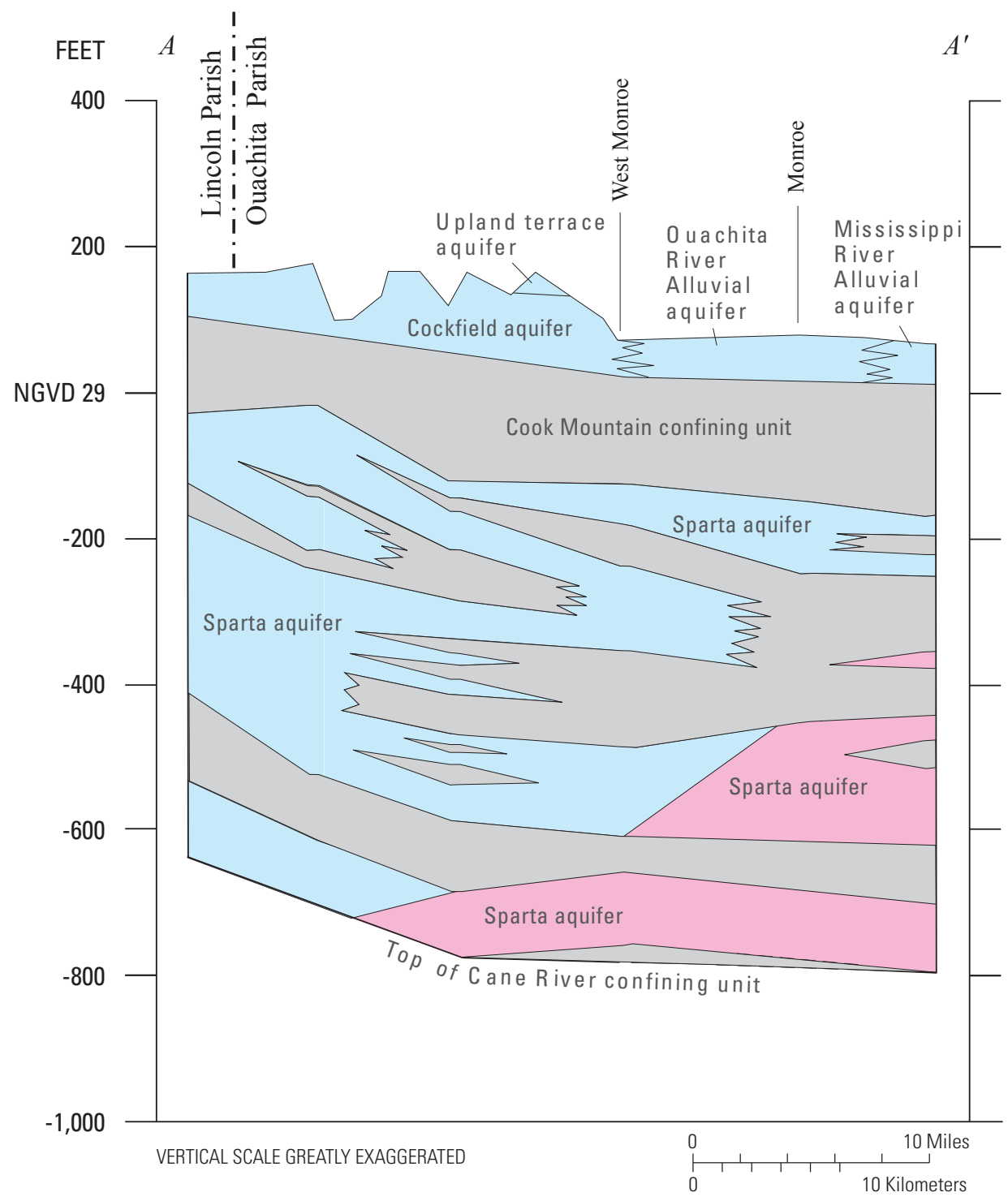

EXPLANATION

Clay

Freshwater in sand

Saltwater in sand
Figure 3. Generalized west-toeast hydrogeologic section through Ouachita Parish, Louisiana (Brantly and others, 2002).

Table 3. Summary of selected water-quality characteristics for freshwater in the Sparta aquifer in Ouachita Parish, Louisiana, 1941-2007 (U.S. Geological Survey, 2008b).

[Values are in milligrams per liter, except as noted. ${ }^{\circ} \mathrm{C}$, degrees Celsius; PCU, platinum cobalt units; $\mu \mathrm{S} / \mathrm{cm}$, microsiemens per centimeter at $25^{\circ} \mathrm{C}$; $\mathrm{SU}$, standard units; $\mu \mathrm{g} / \mathrm{L}$, micrograms per liter; SMCL, Secondary Maximum Contaminant Level for drinking water established by the U.S. Environmental Protection Agency (2006); NA, not applicable]

\begin{tabular}{|c|c|c|c|c|c|c|c|c|c|}
\hline & $\begin{array}{c}\text { Temperature } \\
\left({ }^{\circ} \mathrm{C}\right)\end{array}$ & $\begin{array}{l}\text { Color } \\
\text { (PCU) }\end{array}$ & $\begin{array}{c}\text { Specific } \\
\text { conductance, } \\
\text { field } \\
\left(\mu \mathrm{S} / \mathrm{cm} \text { at } 25^{\circ} \mathrm{C}\right)\end{array}$ & $\begin{array}{l}\text { pH field } \\
\text { (SU) }\end{array}$ & $\begin{array}{l}\text { Hardness } \\
\text { (as } \mathrm{CaCO}_{3} \text { ) }\end{array}$ & $\begin{array}{c}\text { Chloride, } \\
\text { filtered } \\
\text { (as CI) }\end{array}$ & $\begin{array}{c}\text { Iron, } \\
\text { filtered } \\
(\mu \mathrm{g} / \mathrm{L} \text { as } \mathrm{Fe})\end{array}$ & $\begin{array}{c}\text { Manganese, } \\
\text { filtered } \\
\text { ( } \mu \mathrm{g} / \mathrm{L} \text { as } \mathrm{Mn} \text { ) }\end{array}$ & $\begin{array}{c}\text { Dissolved } \\
\text { solids, } \\
\text { filtered }\end{array}$ \\
\hline Median & 23 & 40 & 900 & 8.4 & 4 & 92 & 80 & $<10$ & 580 \\
\hline 10th percentile & 22 & 15 & 450 & 7.8 & 2 & 19 & 20 & $<10$ & 300 \\
\hline 90th percentile & 25 & 85 & 1,280 & 8.8 & 14 & 220 & 376 & 35 & 740 \\
\hline Number of samples & 28 & 66 & 57 & 82 & 229 & 230 & 42 & 26 & 41 \\
\hline $\begin{array}{r}\text { Percent of samples } \\
\text { meeting SMCLs }\end{array}$ & NA & 6 & NA & 45 & NA & 98 & 82 & 92 & 41 \\
\hline \multicolumn{10}{|c|}{ SMCLs } \\
\hline & NA & 15 & NA & $6.5-8.5$ & NA & 250 & 300 & 50 & 500 \\
\hline
\end{tabular}


About 270 wells are screened in shallow aquifers and primarily used for domestic purposes or irrigation. Twenty-one wells screened in alluvial aquifers and one well screened in the upland terrace aquifer had yields of $100 \mathrm{gal} / \mathrm{min}$ or more. These larger yielding wells were mostly for irrigation or industrial use. Withdrawals from the shallow aquifers in 2005 totaled about 1.2 Mgal/d in Ouachita Parish.

Because the rate of water withdrawals from the Mississippi River alluvial aquifer has been low, water levels in the aquifer have not shown long-term declines. Water levels in well Ou-151, screened in the Mississippi River alluvial aquifer in eastern Ouachita Parish, fluctuated seasonally by about 10 to $15 \mathrm{ft}$ from 1953 to 2008 (fig. 4).

The Cockfield aquifer is present as scattered erosional remnants below terrace deposits, primarily in western parts of Ouachita Parish. In most of central and eastern Ouachita Parish, erosion by ancestral streams and the Ouachita River has removed the Cockfield aquifer. The Cockfield aquifer contains fine to medium sand. Reported well yields are about $20 \mathrm{gal} / \mathrm{min}$. Yields as high as $100 \mathrm{gal} / \mathrm{min}$ are possible in some areas but could cause dewatering because of the limited extent and shallow depths of the aquifer.

\section{Sparta Aquifer}

The Sparta aquifer underlies all of Ouachita Parish and is the most important source of groundwater. In the parish, the base of the aquifer ranges from 650 to $850 \mathrm{ft}$ below NGVD 29, and the aquifer ranges from about 600 to $700 \mathrm{ft}$ in thickness. The Sparta aquifer generally consists of layers of sand, silt, and clay. Although the Sparta aquifer is also known locally as the "Sparta Sand," in some areas the aquifer contains mostly silt and clay. In most areas, the Sparta aquifer contains one or more sands at least $50 \mathrm{ft}$ thick and locally contains sands 100 to $250 \mathrm{ft}$ thick.

About 344 wells registered with Louisiana DOTD are screened in the Sparta aquifer in the parish. Many of the wells (152) are privately owned domestic wells, but about 117 of the wells are used for public supply. Reported yields from wells ranged from less than 10 to about $1,720 \mathrm{gal} / \mathrm{min}$. In 2005, about $22 \mathrm{Mgal} / \mathrm{d}$ were withdrawn from the Sparta aquifer in the parish (table 1).

Water levels in the Sparta aquifer in Ouachita Parish ranged from about 40 to $200 \mathrm{ft}$ below NGVD 29 in 2006. The lowest water levels were at West Monroe where about

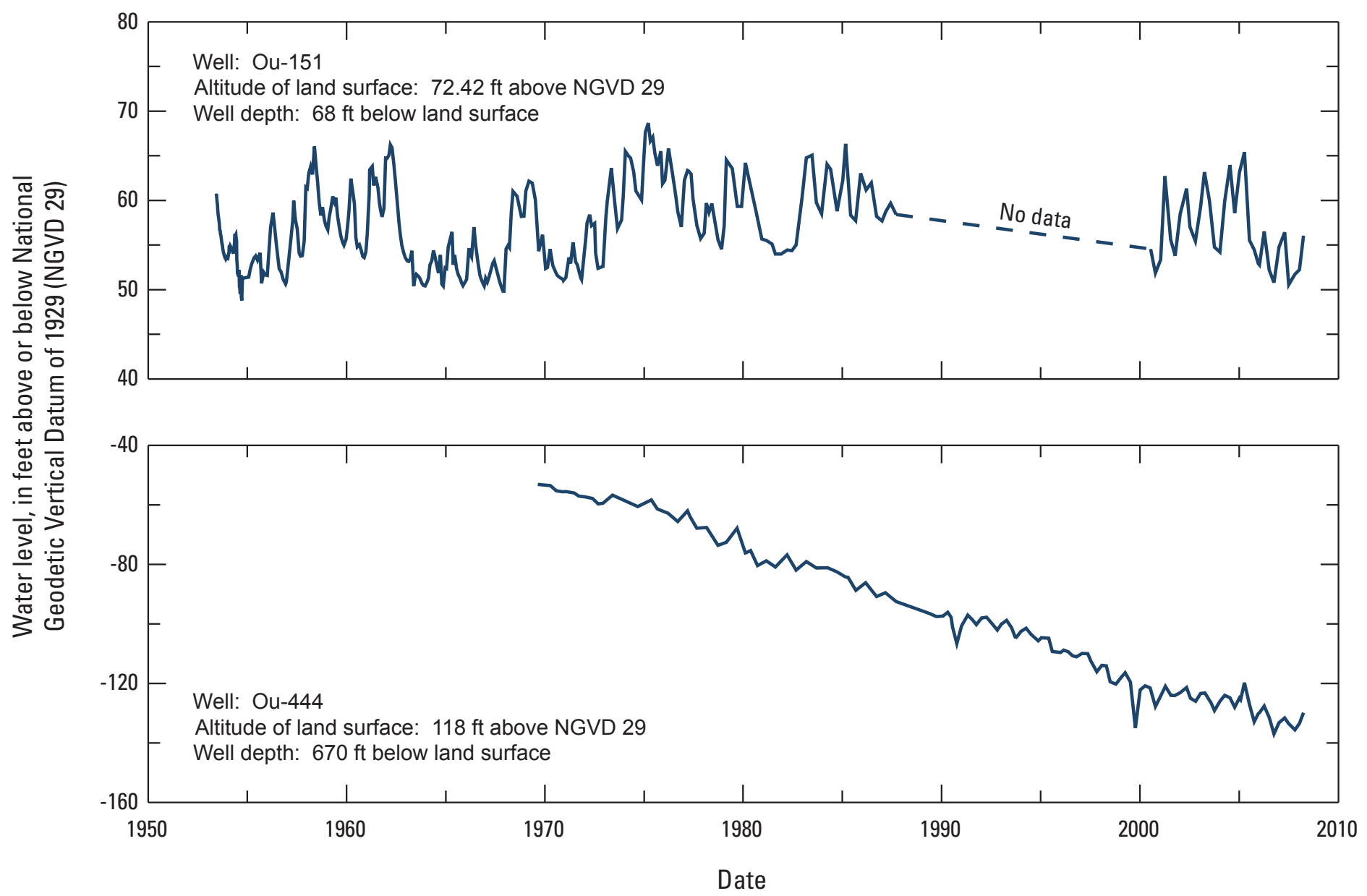

Figure 4. Water levels in well Ou-151 screened in the Mississippi River alluvial aquifer and well Ou-444 screened in the Sparta aquifer in Ouachita Parish, Louisiana (see fig. 1 for well locations). 
$14 \mathrm{Mgal} / \mathrm{d}$ were withdrawn in 2005. In the West Monroe area, water levels have declined about $300 \mathrm{ft}$ since the early 1900s as a result of withdrawals, mostly for public supply and industry. Withdrawals in this area have altered the flow pattern in the Sparta aquifer throughout most of its extent in northern Louisiana. Prior to development, water in the Sparta aquifer generally moved from northwest to southeast. Current (2009) water movement in the aquifer is generally toward the West Monroe area. The hydrograph for well Ou-444 shows that during the period 1970-2008, water-level declines of as much as $80 \mathrm{ft}$ have occurred in the Sparta aquifer in the parish.

Selected water-quality data from wells screened in the Sparta aquifer are summarized in table 3. In much of Ouachita Parish, the Sparta aquifer yields freshwater that is soft and has concentrations of chloride, iron, and manganese that generally do not exceed the EPA's SMCLs. Chloride concentrations in freshwater-yielding wells generally range between 19 and $220 \mathrm{mg} / \mathrm{L}$. Values for color and concentrations of dissolved solids generally exceed SMCLs, the latter because of elevated chloride concentrations (water containing $100 \mathrm{mg} / \mathrm{L}$ or more chloride).

In most of Ouachita Parish, the Sparta aquifer contains freshwater that is underlain with saltwater (water with a chloride concentration that exceeds $250 \mathrm{mg} / \mathrm{L}$ ) at the base of the aquifer. Chloride concentrations in the Sparta aquifer increase with depth. Saltwater increases in thickness (more sands become salty) toward the eastern boundary. A few miles to the east in Richland Parish, the aquifer contains only saltwater. Throughout the parish, there is a risk of saltwater encroachment in the Sparta aquifer, mostly through upconing, during which pumping wells draw water up from deeper, salty areas of the aquifer into shallower, freshwater areas.

\section{Surface-Water Resources}

The Ouachita River and Bayou de Siard are primary sources of fresh surface water in Ouachita Parish. Most of the water withdrawn from these sources is used for public supply, industry, power generation, and irrigation. Other bodies of freshwater in the parish include Bayous Boeuf, Choudrant, Bartholomew, de Loutre, D'Arbonne and Lafourche; North Cheniere and Cypress Creeks; Cheniere and Wham Brakes; and Black Bayou Lake.

About $105 \mathrm{Mgal} / \mathrm{d}$ of water were withdrawn from the Ouachita River in 2005 for industry (13 Mgal/d), power generation $(87 \mathrm{Mgal} / \mathrm{d})$, and irrigation (5 Mgal/d). Most of the water used for power generation and industry was for oncethrough cooling and was discharged back into the river. The average discharge for the Ouachita River near Monroe is 18,900 cubic feet per second (12,200 Mgal/d) (U.S. Geological Survey, 2008c). Selected water-quality data for the Ouachita River are summarized in table 4. Water in the Ouachita River is soft. Chloride and sulfate concentrations meet the EPA's SMCLs, but

Table 4. Summary of selected water-quality characteristics for the Ouachita River and Bayou de Siard in Ouachita Parish, Louisiana, 1954-2000 (U.S. Geological Survey, 2008b).

[Values are in milligrams per liter, except as noted. $\mu \mathrm{S} / \mathrm{cm}$, microsiemens per centimeter at $25^{\circ} \mathrm{C} ; \mu \mathrm{g} / \mathrm{L}$, micrograms per liter; SU, standard units; NA, not applicable; -- no value; SMCL, Secondary Maximum Contaminant Level for drinking water established by the U.S. Environmental Protection Agency (2006)]

\begin{tabular}{|c|c|c|c|c|c|c|c|c|c|c|}
\hline & $\begin{array}{c}\text { Specific } \\
\text { conductance, } \\
\text { field } \\
\left(\mu \mathrm{S} / \mathrm{cm} \text { at } 25^{\circ} \mathrm{C}\right)\end{array}$ & $\begin{array}{l}\text { Oxygen, } \\
\text { dissolved }\end{array}$ & $\begin{array}{l}\mathrm{pH}, \\
\text { field } \\
\text { (SU) }\end{array}$ & $\begin{array}{l}\text { Hardness } \\
\text { (as } \mathrm{CaCO}_{3} \text { ) }\end{array}$ & $\begin{array}{l}\text { Calcium, } \\
\text { filtered } \\
\text { (as Ca) }\end{array}$ & $\begin{array}{c}\text { Magnesium, } \\
\text { filtered } \\
\text { (as } \mathbf{M g} \text { ) }\end{array}$ & $\begin{array}{l}\text { Sodium, } \\
\text { filtered } \\
\text { (as } \mathrm{Na} \text { ) }\end{array}$ & $\begin{array}{c}\text { Chloride, } \\
\text { filtered } \\
\text { (as CI) }\end{array}$ & $\begin{array}{l}\text { Sulfate, } \\
\text { filtered } \\
\text { (as } \mathrm{SO}_{4} \text { ) }\end{array}$ & $\begin{array}{c}\text { Iron, } \\
\text { filtered } \\
(\mu \mathrm{g} / \mathrm{L} \\
\text { as Fe) }\end{array}$ \\
\hline \multicolumn{11}{|c|}{ Ouachita River } \\
\hline Median & 210 & 6.2 & 6.6 & 37 & 11 & 2.2 & 26 & 40 & 10 & 250 \\
\hline 10 th percentile & 97 & 3 & 6.0 & 20 & 6 & 1.3 & 10 & 17 & 6 & 140 \\
\hline 90th percentile & 450 & 9.5 & 7.0 & 62 & 19 & 4.1 & 64 & 93 & 18 & 470 \\
\hline Number of samples & 231 & 160 & 217 & 189 & 189 & 189 & 188 & 193 & 203 & 15 \\
\hline $\begin{array}{r}\text { Percent of samples } \\
\text { meeting SMCLs }\end{array}$ & NA & NA & 34 & NA & NA & NA & NA & 100 & 100 & 73 \\
\hline \multicolumn{11}{|c|}{ Bayou de Siard } \\
\hline Median & 93 & 8 & 7.1 & 26 & 7.3 & 2 & 7 & 6.9 & 2 & -- \\
\hline 10th percentile & 71 & 7.1 & 6.6 & 22 & 5.9 & 1.7 & 5 & 5.1 & .4 & -- \\
\hline 90th percentile & 128 & 8.7 & 7.4 & 34 & 9.1 & 2.9 & 13 & 16 & 3.5 & -- \\
\hline Number of samples & 6 & 4 & 6 & 6 & 6 & 6 & 6 & 6 & 6 & 0 \\
\hline $\begin{array}{r}\text { Percent of samples } \\
\text { meeting SMCLs }\end{array}$ & NA & NA & 83 & NA & NA & NA & NA & 100 & 100 & -- \\
\hline \multicolumn{11}{|c|}{ SMCLs } \\
\hline & NA & NA & $6.5-8.5$ & NA & NA & NA & NA & 250 & 250 & 300 \\
\hline
\end{tabular}


$\mathrm{pH}$ generally is low (less than $7 \mathrm{mg} / \mathrm{L}$ ) and met the SMCL in only 34 percent of samples. Iron concentrations also exceeded the SMCL in 27 percent of samples.

About $11 \mathrm{Mgal} / \mathrm{d}$ of water were withdrawn from Bayou de Siard for public supply during 2005. Streamflow data for Bayou de Siard were not available, but there is little flow in the stream because of a dam constructed across the bayou near its confluence with the Ouachita River. Analyses of six samples collected from the bayou in Ouachita Parish indicate the water quality generally is within the EPA's SMCLs (table 4).

\section{References}

Brantly, J.A., Seanor, R.C., and McCoy, K.L., 2002, Louisiana ground-water map no. 13-Hydrogeology and potentiometric surface, October 1996, of the Sparta aquifer in northern Louisiana: U.S. Geological Survey Water-Resources Investigations Report 02-4053, 3 sheets.

Rogers, J.E., Calandro, A.J., and Gaydos, M.W., 1972, Water resources of Ouachita Parish, Louisiana: Department of Conservation, Louisiana Geological Survey, and Louisiana Department of Public Works Water Resources Bulletin no. 14, $118 \mathrm{p}$.

Sargent, B.P., 2007, Water use in Louisiana, 2005: Louisiana Department of Transportation and Development Water Resources Special Report no. 16, 133 p.

U.S. Environmental Protection Agency, 1992, Secondary drinking water regulations - guidance for nuisance chemicals: U.S.

Environmental Protection Agency publication EPA 810/K92-001, 4 p., accessed July 29, 2009, at http://www.epa.gov/ safewater/consumer/2ndstandards.html.

U.S. Environmental Protection Agency, 2006, 2006 Edition of the drinking water standards and health advisories: Washington D.C., U.S. Environmental Protection Agency, Office of Water, $12 \mathrm{p}$.

U.S. Geological Survey, 2008a, Ground-water levels for Louisiana: U.S. Geological Survey digital dataset, accessed May 22, 2008, at http://nwis.waterdata.usgs.gov/la/nwis/ gwlevels.

U.S. Geological Survey, 2008b, Water-quality samples for Louisiana: U.S. Geological Survey digital dataset, accessed May 22, 2008, at http://nwis.waterdata.usgs.gov/la/nwis/ qwdata.

U.S. Geological Survey, 2008c, StreamStats: U.S. Geological Survey digital dataset, accessed July 28, 2008, at http:// streamstats.usgs.gov/gages/viewer.htm.

\section{By Dan J. Tomaszewski, John K. Lovelace, and Jason M. Griffith}

\section{For additional information, contact:}

Director, USGS Louisiana Water Science Center 3535 S. Sherwood Forest Blvd., Suite 120

Baton Rouge, LA 70816

E-mail: dc_la@usgs.gov

Fax: (225) 298-5490

Telephone: (225) 298-5481

Home Page: http://la.water.usgs.gov
This fact sheet was published by the U.S. Geological Survey, in cooperation with the Louisiana Department of Transportation and Development (DOTD). Thanks are given to Zahir "Bo" Bolourchi, Director, Water Resources Programs, Louisiana Department of Transportation and Development, who contributed to the content and design of the fact sheet. 